\title{
臨床経験人格テスト $(\mathrm{MMPI})$ で女性型の性格偏 位傾向を示す男性慢性疼痛患者に対す る加味幍遙散エキス顆粒剂の効果
}

Efficacy of "Kami-syouyou-san" for Male Chronic Pain Patients who Suffered from Pathological Character Change, So-called "Converted $\mathrm{V}$ pattern", which is Typically Observed in Female Neurosis

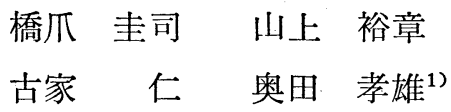

\author{
Keiji Hashizume Hiroaki Yamagami \\ Hitoshi Furuya Takao OKudA ${ }^{1)}$
}

\begin{abstract}
要約 慢性疼痛患者では, 痛みに反応して生来の性格偏位が増幅され，神経症を併発してい る場合が多い。難治性の神経症の一型に，心気症傾向とヒステリ一傾向が高い型（転換 $\mathrm{V}$ 型） がある。元来女性に多い型であるが，男性にもみられ，治療抵抗性で抗不安薬等では不十分な ことが多い。しかし女性では加味幍遥散がしばしば奏効する。そこで, 転換 $\mathrm{V}$ 型を示す男性の 慢性疼痛患者で, 抗不安薬等の効果に限界があった15例 (平均54.3土13.7歳) に対し, 加味逍 遥散エキス顆粒剤（1日量 $7.5 \mathrm{~g}$ を 4 週間）を投与し，その有効性を検討した。その結果，有 効率は33\%で，全体では「やや有効」であった。臨床効果は鎮痛薬としてではなく，抗不安薬 様の作用として現れた。無効例は性格偏位のポイントが高い例に多く，神経症の重症度が加味 逍遥散の効果に反映された形となった。眠気，ふらつき等の副作用なしに，抗不安作用を期待 できる点が大きな特長であった。
\end{abstract}

\section{はじめに}

原因を問わず，何らかの痛みに長期間苦しめら れると，陰性感情に陥り易いものである。そのよ らな傾向は, 痛みに反応してさらに増幅され, や がて心身交互作用も㗢いて，神経症状態となって くる。その神経症状態がまた痛みを強めるという 悪循環が成立して，慢性疼痛はますます遷延化す る。当科では種々の疼痛患者に対して神経ブロッ
ク療法を行らが，慢性疼痛においては，随伴する 神経症状態に対する治療を特こなわないかぎり， 痛及の治療に成功することは，かなり困難なこと である。

神経症の治療は，一般に薬物投与が中心となる が，この種の神経症は単一ではない。そこで我々 は，人格テスト（MMPI，S R Q-D等）を施行 して，神経症の傾向（らつ，ヒステリ一等）を判 断し，それに応じて抗うつ薬，抗不安薬等を投与

1) 医, 奈良県立医科大学麻酔科ペインクリニック，奈良

1) Department of Anesthesiology, Nara Medical University, Nara 
表 1 症例一覧

\begin{tabular}{|c|c|c|c|c|c|c|c|}
\hline \multirow{2}{*}{ 症例 } & \multirow{2}{*}{ 年齢 } & \multirow{2}{*}{ 主訴 } & \multirow{2}{*}{ 原疾患 } & \multicolumn{4}{|c|}{ 加味覓遥散投与前の治療内容 } \\
\hline & & & & 神経ブロック & 抗不安薬 & 抗らつ薬 & 向精神薬 \\
\hline 1. & 32 & 腰痛 & 帯状疮疹後神経痛 & + & + & - & - \\
\hline 2. & 55 & 頭痛 & 自律神経失調症 & + & + & + & + \\
\hline 3. & 67 & 側胸部痛 & 術後肋間神経損傷 & + & + & + & - \\
\hline 4. & 51 & 肚門痛 & 直腸カルチノイド & + & + & + & - \\
\hline 5. & 44 & 腰下肢痛 & 腎癌腰椎転移 & + & + & + & - \\
\hline 6. & 38 & 頸部痛 & 頸椎症 & + & + & + & - \\
\hline 7. & 41 & 前額部痛 & 術後三叉神経損傷 & + & + & + & - \\
\hline 8. & 80 & 前胸部痛 & 帯状疮疹後神経痛 & + & + & + & - \\
\hline 9. & 58 & 腰痛 & 食道癌肝転移 & + & + & + & - \\
\hline 10. & 66 & 前胸部痛 & 術後胁間神経損傷 & + & + & - & - \\
\hline 11. & 38 & 下肢痛 & 血栓性閉塞性血管炎 & + & + & - & - \\
\hline 12. & 61 & 顔面痛 & 三叉神経痛 & + & + & + & - \\
\hline 13. & 59 & 頸部痛 & 頸椎症 & + & + & - & - \\
\hline 14. & 71 & 胸部痛 & 自律神経失調症 & + & + & - & - \\
\hline 15. & 53 & 頸, 肩痛 & 頸椎症 & + & + & - & - \\
\hline
\end{tabular}

(平均 $54.3 \pm 13.7$ 歳)

することにしている。しかしこれらの薬物で効果 不十分な例があり，漢方薬を応用することも少な くない1) 3)。

そのような性格偏位の一型に，人格テスト（M MP I ）上，心気症傾向とヒステリー傾向が高い 型がある。これは転換 $\mathrm{V}$ 型と称され（詳細は本文 で述べる)，女性によくみられる型であるが，男 性の慢性疼痛患者にも少なくない。一般に不定愁 訴が多く，治療に抵抗性で，抗不安薬等を増量し ても眠気やふらつきが先に出現して，効果不十分 に終わることが多いものである。このような症例 に加味幍遥散を使用してみると，女性ではしばし ば有効であるのを経験する。そこで今回我々は， 転換 $\mathrm{V}$ 型を示す，すなわち女性型の性格偏位傾向 を示す男性の慢性疼痛患者に対して加味逍遥散を 投与し，その有効性を検討してみた。若干の知見 を得たので報告する。

\section{対象と方法}

対象は，人格テスト（MMP I ）の結果が，心 気症傾向とヒステリ一傾向の高い転換 $\mathrm{V}$ 型であっ た男性慢性疼痛患者15名である。証の判定は厳密 に抽こなわなかったが，実証と考兄られた患者は
最初から除外した。年齢は 32 ～80歳 (平均 $54.3 \pm$ 13.7 歳), 原疾患は手術後の末梢神経損傷 3 例, 癌性疼痛 3 例, 頸椎症 3 例, 帯状疱疹後神経痛 2 例，自律神経失調症 2 例，三叉神経痛 1 例，血栓 性閉塞性血管炎 1 例であった。全例，神経ブロッ ク療法で疼痛の治療を捛こなうと同時に，神経症 に対して抗不安薬，抗うつ薬，向精神薬等を投与 していたが，それらの効果がプラトーに達してい た症例である(詳細を表 1 亿示す)。

従来の治療を原則的に継続したまま，加味逍遥 散エキス顆粒剤 1 日量 $7.5 \mathrm{~g}$ を 4 週間投与した。疼 痛, 不安, 不眠等の愁訴の改善度を, 加味逍遥散 投与前を10，愁訴なしを 0 とする11段階で投与終 了時に患者に評価させ，以下の基準に従って判定 した。

$$
\begin{aligned}
& 0 \sim 2 \text { : 著効 } \\
& 3 \sim 5 \text { : 有効 } \\
& 6 \sim 8 \text { : やや有効 } \\
& 9 \sim 10: \text { 無効 }
\end{aligned}
$$

また，(著効例数十有効例数／総数 $\times 100 \%$ ） 計算し，有効率とした。また，副作用について最 低週 1 回問診を行い，記録した。 
表 2 MMPI の尺度

\begin{tabular}{|c|c|c|}
\hline 妥当性尺度 & $\begin{array}{l}? \\
\mathrm{~L} \\
\mathrm{~F} \\
\mathrm{~K}\end{array}$ & 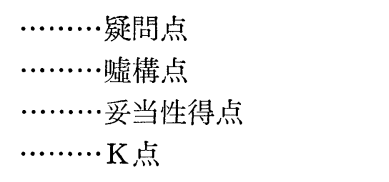 \\
\hline 臨床尺度 & $\begin{array}{l}1(\mathrm{Hs}) \\
2(\mathrm{D}) \\
3(\mathrm{Hy}) \\
4(\mathrm{Pd}) \\
5(\mathrm{Mf}) \\
6(\mathrm{~Pa}) \\
7(\mathrm{Pt}) \\
8(\mathrm{Sc}) \\
9(\mathrm{Ma})\end{array}$ & 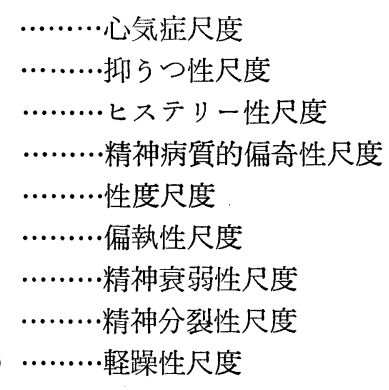 \\
\hline 追加尺度 & $\begin{array}{l}0(\mathrm{Si}) \\
\text { その他 }\end{array}$ & ………社会的向性尺度 \\
\hline
\end{tabular}

注) MMPI と転換 V 型について ${ }^{4) 5)}$

MMPI (Minnesota Multiphasic Personality Inventory ミネソタ多面的人格目録) は, ミネソ タ大学で作られた目録方式の人格テストである。 目録方式とは，多数の質問を列記し，それに対す る回答を記入させる方式の人格テストである。こ の種のテストは多数あるが, MMPI は最も研究 され，診断的価值が高く評価されている。1. 人格 理論よりも医学的診断などの経験的妥当性を重視 している点，2. 目録方式にありがちな，被検者の 回答態度による応答の歪みを検出し，それを修正 するようになっている点が特徵である。

実施にあたっては，質問用紙 (550項目)を手渡 し，「そう」，「ちがう」，「どちらでもない」で回 答させる。これを採点すると, 検査尺度の素点が 得られ, 修正点で修正し, さらに標準得点 ( T 点）に換算すると被検者のプロフィルが作成でき る（実際には，各尺度の T点換算スケールを印刷 した用紙があり，それに各尺度の修正点数を記入 すれば，自動的に T点に換算され簡便にプロフィ ルが図示できるようになっている)，プロフィル は，表 2 に示すように，回答態度を判定する妥当 性尺度 4 項目（？，L，F，K），人格の諸側面 を判定する臨床的尺度 9 項目（1から 9 ），拈よ びいくつかの追加尺度（ 0 ，その他）から構成
される。各尺度の $\mathrm{T}$ 点が，40ポイント以上 55 ポイ ント未満は正常範囲である。 55 ポイント以上は 高得点，70ポイントを越光る場合は病的に高いと 見なす。したがって妥当性尺度のいずれかが70ポ イントを越えている場合は，プロフィルの信頼性 に問題があり（例究ば患者が率直に回答していな い), 慎重な解釈が要求される（今回対象とした 症例の妥当性尺度は, 全例 70ポイント以下であ る)。

我々の外来を訪れるよらな，慢性疼痛に反応し て発症した神経症患者では，尺度 1 (心気症), 尺度 2 (抑らつ), 尺度 3（転換ヒステリー）が 高值を示すことが多いが，大体二つのパターンが ある。尺度 2 が高い場合と図 1 のような尺度 1 , 3 が高く尺度 2 が低い場合である。前者は抑らつ 性神経症と考えられ，抗らつ薬を投与する。後者 が転換 $\mathrm{V}$ 型であり，「転換」とは「転換ヒステリ 一」のそれで，「V型」とは，1，3が高く， 2 が低いプロフィルが谷間 (V字型) の形を取るか らである。女性に普遍的にみられるプロフィル で, 頭痛, 胸痛, 腰痛等の痛みの訴光, 食欲不 振, 悪心等の摂食に関する訴えの他, 疲労感, め まい，睡眠障害等の不定愁訴が多く，種々の治療 に抵抗性であるとされている。

\section{結 果}

表 3 に各症例の MMPI の 1，3 尺度の T点, および加味逍遥散による臨床効果を示す。著効 1 例，有効 4 例，やや有効 4 例，無効 6 例で，有効 率は33\%であった。全平均で，愁訴は10から6.9 士2.7 へと減じ，全体として「やや有効」であっ た。効果のあった症例では, 「痛みが柔らかく感 じる」「とくに変化ないよらだが服用を忘れると 痛みが強まる」「気分的に楽」等のコメントが得 られた。

無効例には，MMPI ポイントが高い例（80ポ イント以上）が多い傾向があったため，1，3 尺 度のいずれかが80ポイントを越えている 6 例（高 得点群) と, 80 ポイントまでの 9 例（低得点群） とを比較したところ, 高得点群の愁訴改善度は10 
MMPI冊子式記録用紙（II 型）
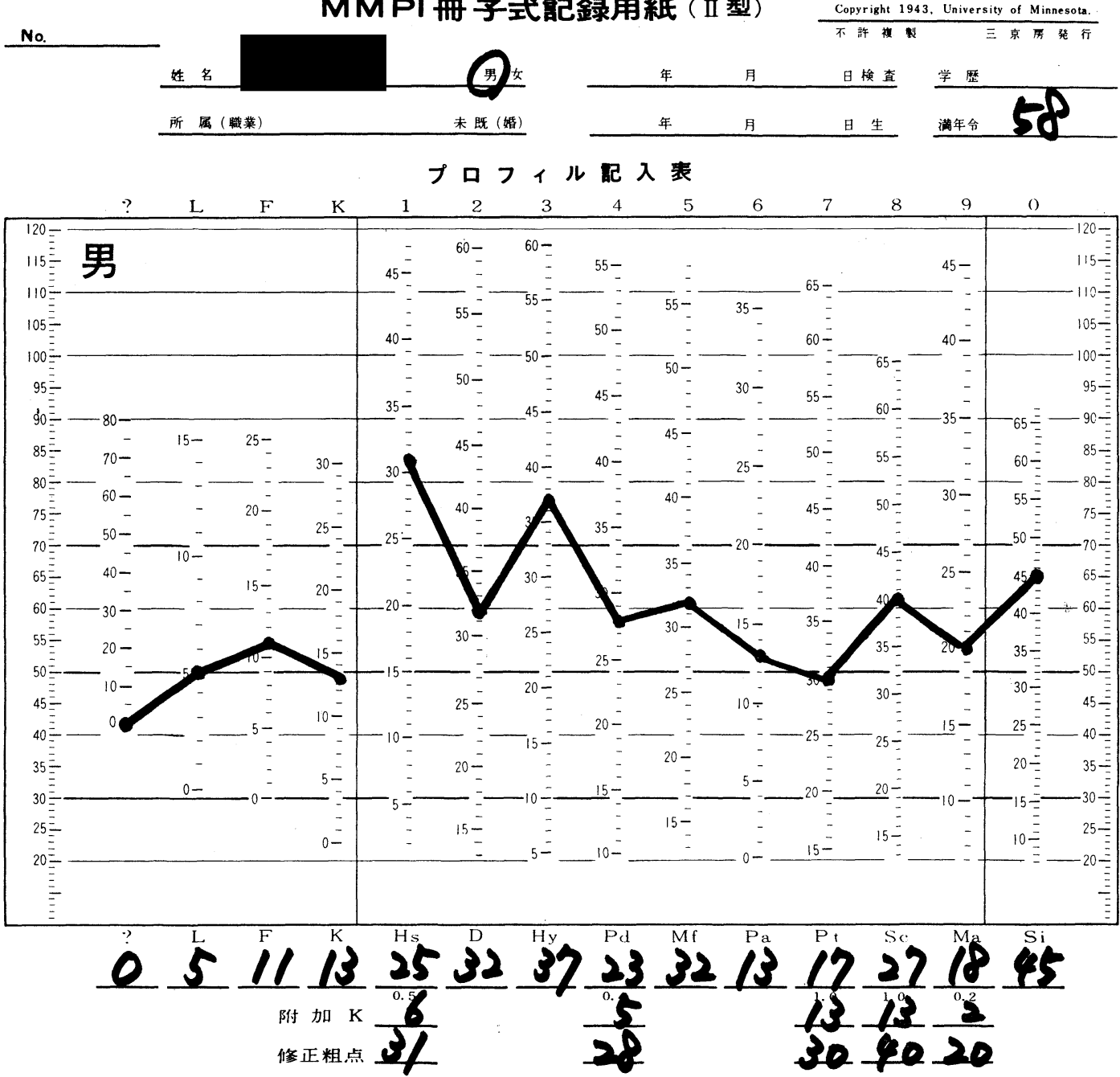

\begin{tabular}{|c|c|c|}
\hline 1305824 & & 追加尺度 \\
\hline プフィル所見 & 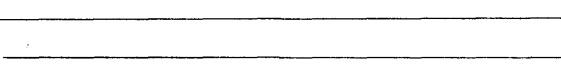 & A \\
\hline & & MAS \\
\hline & & Es \\
\hline & & Lb \\
\hline & & $\mathrm{Ca}$ \\
\hline & & Dy \\
\hline & & $\mathrm{Re}$ \\
\hline & $D_{2}$ & Pr \\
\hline & & $s t$ \\
\hline
\end{tabular}

図1プロフィル 
表 3 結果

\begin{tabular}{ccccc}
\hline 症例 & $\begin{array}{c}\text { MMP I の } \\
\text { 第一尺度 }\end{array}$ & $\begin{array}{c}\text { 第三尺度 } \\
\text { 加味覓遥散 } \\
\text { の効果 }\end{array}$ & 副作用 \\
\hline 1. & 71 & 73 & $10 \rightarrow 7$ & なし \\
2. & 77 & 70 & $10 \rightarrow 5$ & なし \\
3. & 76 & 70 & $10 \rightarrow 4$ & なし \\
4. & 83 & 73 & $10 \rightarrow 10$ & なし \\
5. & 71 & 69 & $10 \rightarrow 7$ & なし \\
6. & 69 & 69 & $10 \rightarrow 10$ & 下痢 \\
7. & 85 & 66 & $10 \rightarrow 8$ & なし \\
8. & 61 & 56 & $10 \rightarrow 5$ & なし \\
9. & 83 & 78 & $10 \rightarrow 9$ & なし \\
10. & 71 & 77 & $10 \rightarrow 4$ & なし \\
11. & 80 & 70 & $10 \rightarrow 10$ & なし \\
12. & 77 & 80 & $10 \rightarrow 8$ & なし \\
13. & 81 & 65 & $10 \rightarrow 9$ & なし \\
14. & 66 & 55 & $10 \rightarrow 1$ & なし \\
15. & 69 & 58 & $10 \rightarrow 6$ & なし \\
\hline
\end{tabular}

(平均 $10 \rightarrow 6.9 \pm 2.7$ )

$\rightarrow 9.0 \pm 0.9$ (無効) 飞対し, 低得点群は10 $\rightarrow 5.4 \pm$ 2.5 (有効) で, 有意差が認められた $(\mathrm{P}<0.01) 。$ 副作用は 1 例のみに軽度の下痢 (一過性) を認 めたが，抗不安薬等でしばしばみられる眠気，ふ らつきはまったくなかった。

\section{考 按}

MM P I に打ける転換 V 型の特徵は先に述べた 通りであるが, 臨床的には女性の慢性頭痛患者 や，多岐にわたる不定愁訴を有する更年期障害患 者などにしばしば見られる型である。易疲労, 神 経の克ぶり, 肩こり, 頭痛, 不眠, 胃腸症状等を 絶えず訴觉続けるタイプの患者が多く, 対処に難 渋するが, しばしば加味逍遥散が奏効することを 経験している。

一方, 男性の慢性疼痛患者に扔いても, 転換 $\mathrm{V}$ 型の患者は少なくない。抗不安薬等の効果に限界 があるので, 漢方薬の応用を検討した結果, 珄格 偏位の傾向が女性型である点より，加味逍遥散が 有効ではないかと考えた。

結果は, 著効 1 例, 有効 4 例, 有効率は $33 \%$, まったくの無効例（愁訴10 $\rightarrow 10 ）$ は 3 例のみで, 痛みを主とする愁訴に対しほぼ良好な結果が得ら
れた。しかし患者のコメントは，鎮痛薬というよ り, 抗不安薬として効果を示唆する内容が多かっ た。これは, 加味逍遥散が直接的な鎮痛作用を発 揮するのではなく, 疼痛を増強させる神経症に対 して，抗不安薬様の作用機序で奏効することを示 すものであろら。加味逍遥散を男性に応用し，有 効であった報告は週去にいくつか散見されるが， いずれも自律神経の不安定性や不定愁訴を目標と しているものが多い677。このことからも加味逍遥 散は，慢性疼痛に反応して発症した神経症やそと れに随伴する自律神経失調状態を鎮静化すること により, 疼痛と神経症の悪循環を断つ効果を有す るのであろら。我々が扱ら神経症は, 疼痛に反応 して二次的に発症したものであるので, 疼痛治療 （神経ブロック療法）と神経症治療の同時進行で 初めて効果が得られる。したがって加味逍遥散 も, 単独で慢性疼痛の治療を成功させるものでは なく，神経ブロック療法等に併用して効果を発揮 すると考觉れる。

次に, 加味逍遥散が無効であった例は, MMP I の T点が高值の症例が多かった。1，3 尺度の いずれかが80ポイントを越えている 6 例と，80ポ イントまでの 9 例を比較すると愁訴改善度には有 意差が認められた。T点は性格偏位の重症度をあ る程度定量的に示すと考兄られるので, 神経症の 重症度が加味逍遥散の効果に反映されたと考えて よいだろう。ということは逆に, 無効例でも用量 依存的に効果が得られた可能性は否定できない。 また，今回使用したのはエキス剤であるので，エ キス剂の限界といらことかも知孔ない。これらの 点は, 今後の検討を要する課題である。

副作用は一過性の軽度の下痢が一例あったが, この症例はもともと自律神経失調症の一症状と思 われる慢性便通異常を伴って扣り, 加味逍遥散に 特異的とは考光にくい。その他に副作用はなく， とくに抗不安薬, 抗うつ薬等でしばしばみられる 眠気，ららつきは見られなかった。慢性疼痛患者 の場合は高齢者も少なくなく, 患者の Quality of Life を考えるとき，眠気，ふらつきは大きな 治療の障害となる。このような副作用を心配せず に, 抗不安作用を期待できる点が, 加味逍遥散の 
大きな特長であると思われた。

な初加味逍遥散の男性応用では，らつ傾向に用

い有効であったとする報告も散見され，興味深い 8)99。我々の疼痛患者にも, うつ傾向の患者は多数 見られるので, 今後はそのよらな患者にも加味逍 遥散の応用を検討し, 機会があれば発表する予定 である。

\section{総 括}

1）人格テスト（MMP I）で，女性型の神経 症傾向 (転換 $\mathrm{V}$ 型) を示す男性慢性疼痛患者15名 に対し，加味覓遥散エキス顆粒剂を投与し，その 効果を検討した。

2 ）有効率は33\%で, 全体では「やや有効」で あった。臨床効果は鎮痛薬としてではなく，抗不 安薬様の作用として現れた。

3) 無効例は性格偏位のポイントが高い例に多 く, 神経症の重症度が加味逍遥散の効果に反映さ れた形となった。

4) 眠気, ふらつき等の副作用なしに, 抗不安 作用を期待できる点が特長といえる。

な括，本論文の要旨は，第42回日本東洋医学会学術
総会（平成 3 年 6 月 15 日 16日, 京都) の席上, 発表 した。

\section{文 献}

1) 山上裕章, 他 : 帯状疱疹後神経痛に対する当帰四 逆加受葉英生姜湯の効果一特にしびれ・こわばり について，漢方医学，13，21-24，1989

2 ) 山上裕章, 他: 加味幍遥散に上る背部痛の鑑別診 断, 日本東洋医学雑誌，42，41-46，1991

3 ) 山上裕章, 他 : 腰部脊椎管狭窄症 (degenerative type）に対する桂枝获苓丸扣よび当帰四逆加乶䒩 英生姜湯の効果, 痛及と漢方， 1，6-10，1991

4) 日本 MMPI 研究会編：日本版 MMPI ハンドブッ ク(増補版), 三京房, 京都, 1973

5 ) J. R. Graham（田中富士夫訳）：MMPI 臨床解 釈の実際, 三京版, 京都, 1985

6) 松田邦夫 : 加味逍遥散有効男性例一自律神経不安 定症の 2 例, 日本東洋医学雑誌，26，158-160, 1976

7 ) 山田光胤, 他: 加味覓遥散の男子への応用, 日本 東洋医学雑誌，30，241-246，1980

8 ）高橋国海, 他 : 加味逍遥散の応用について, 日本 東洋医学雑誌，27，155-158，1977

9）秋田 㦑, 他：治療抵抗性の抑らつ状態に対する 加味逍遥散の治療経験, 漢方医学, 10,35-36, 1986

（1991年 9 月 9 日受付） 